Poznańskie Studia Teologiczne 29(2015), s. 265-282.

doi: $10.14746 /$ pst.2015.29.16

Paulina Hornik ${ }^{1}$

Uniwersytet Śląski w Katowicach

Wydział Teologiczny

\title{
Mistyka czy depresja? Noc ciemna św. Jana od Krzyża a noc psyche
}

Specyfika nocy ciemnej, którą opisuje św. Jan od Krzyża, oraz tego stanu, który specjalistyczna literatura psychologiczna opisuje mianem depresji, pozwala dostrzec wyraźne podobieństwa tych dwóch fenomenów. Opierając się na wiedzy i praktyce terapeutów oraz pracy kierowników duchowych, można wysnuć ten sam wniosek: noc ciemna wiary oraz depresja są doświadczeniami, które przejawiają się w podobny sposób. Czy jednak te obydwa ludzkie doświadczenia są tym samym, czy są raczej dwiema odrębnymi rzeczywistościami? Co je do siebie upodabnia, a co wyróżnia? Czy może mówimy o tym samym zjawisku, ale opisując je z dwóch odmiennych perspektyw (teologicznej i psychologicznej)? Albo też stoimy w obliczu dwóch z gruntu różnych kryzysów?

Niniejszy artykuł stawia sobie za cel znaleźć odpowiedzi na powyższe pytania. Najpierw nakreślone zostaną podstawowe racje przemawiające za koniecznością dialogu psychologii i teologii. W dalszej kolejności przeanalizujemy zjawisko depresji (zarówno z punktu widzenia psychologii, jak i teologii oraz mistyki), starając się ukazać wzajemne różnice oraz elementy wspólne depresji i nocy ciemnej. Zatrzymamy się też pokrótce przy symbolice nocy w ujęciu Doktora Karmelu, aby przejść do nieco szerszego omówienia charakterystyki sanjuanistycznej nocy ciemnej.

Następnie zaprezentowane zostaną stanowiska znawców tematu nocy ciemnej w powiązaniu z depresją, a te rozważania prowadzić będą do przybliżenia koncepcji dezintegracji pozytywnej, autorstwa polskiego psychiatry i psychologa Kazimierza Dąbrowskiego, aby skonfrontować ją z Janową wizją nocy. W końcu spróbujemy dokonać pewnego rodzaju syntezy mistyczno-psychologicznej.

Istnieje już nieco literatury na interesujący nas temat. $\mathrm{Na}$ gruncie polskim ukazała się m.in. publikacja Jerzego Skawronia OCarm, pt. Noc ducha i dezinte-

\footnotetext{
${ }^{1}$ Mgr lic. kan. Paulina Hornik - doktorantka wydziału teologicznego Uniwersytetu Śląskiego, specjalizuje się w duchowości karmelitańskiej, pisze rozprawę doktorską na podstawie pism św. Jana od Krzyża.
} 
gracja pozytywna (wyd. Karmelitów Bosych, Kraków 2007) i książka Joanny Gic Noc czynna wg św. Jana od Krzyża a psychologia (w ramach serii Biblioteca Carmelitanum, nr 9, wyd. Flos Carmeli, Poznań 2009). Na język polski przetłumaczono również książkę autorstwa amerykańskiego lekarza, wykładowcy akademickiego i teologa, Geralda G. Maya, Ciemna noc duszy. Depresja a kryzys duchowy oczami psychiatry (wyd. WAM, Kraków 2012).

Z publikacji obcojęzycznych można przywołać chociażby tytuły książek wydanych w języku hiszpańskim: Noche oscura y depresión. Crisis espirituales y psicológicas: naturaleza y diferencias (Regina Bäumer y Michael Plattig), stanowiąca zbiór artykułów będących owocem konferencji, która odbyła się w 2008 roku w Münster (Instytut Duchowości tamtejszego Uniwersytetu Filozofii i Teologii od wielu lat zajmuje się problemem relacji kryzysu duchowego i kryzysu psychicznego), bądź też Mistica y depresión. San Juan de la Cruz pióra Francisco J.A. Rodrigueza.

Niniejszy artykuł ma na celu dokonanie pewnego rodzaju syntezy tego, co zostało dotychczas powiedziane na temat współzależności mistycznych stanów nocy ciemnej i depresji, jak również porównanie tych dwóch fenomenów, w świetle nowych badań specjalistów z obydwu dyscyplin wiedzy - teologii i psychologii. Przyjrzyjmy się zatem założeniom i perspektywom wzajemnej współpracy tych dwóch dyscyplin nauki.

\section{Teologia jako ostateczna perspektywa sensu dla psychologii}

„Chcę poznać Boga i duszę" - te słowa św. Augustyna wytyczyły zakres psychologii dla kolejnych wieków. Chociaż może on sam nie zdawał sobie w pełni z tego sprawy, jego własne spojrzenie zarówno na Boga, jak i na duszę czyniło z teologii i psychologii jeden konglomerat, wiążąc obie dziedziny nauki siecią wzajemnych powiązań i zależności².

W późniejszych epokach to pokrewieństwo teologii i psychologii nie było już tak oczywiste jak w czasach św. Augustyna i bezpośrednio następujących po nim. Traktowanie obu tych dziedzin niejednokrotnie daleko odbiegło od myśli Augustyńskiej. Ich wspólne drogi nieraz rozeszły się na tyle, iż niemałego wysiłku wymagało odnalezienie sposobów, aby je na nowo powiązać. Może zrodzić się pytanie, czy jest to w ogóle potrzebne i pożyteczne, a także, czy istnieje jakaś wspólna płaszczyzna porozumienia między nimi. Bez wątpienia teologia i psychologia spotykają się w jednym punkcie. W kręgu zainteresowań obu znajduje się tajemnica człowieka. Teologia zgłębia tę tajemnicę jako zakorzeniona w słowie rozmowa o Bogu i człowieku, natomiast psychologia ujmuje człowieka jako

${ }^{2}$ G.S. Brett, Historia psychologii, PWN, Warszawa 1969, s. 193, za: J. Gic, Noc czynna wg św. Jana od Krzyża a psychologia, Poznań 2009, s. 7. 
byt relacyjny, ,istotę społeczną”, ale jednocześnie autonomiczną; otwartą także na transcendencję ${ }^{3}$.

$\mathrm{Na}$ przestrzeni lat dialog psychologii z teologią uważany był za bezużyteczny lub niemożliwy. Niedocenianie w pracy psychoterapeutycznej wymiaru duchowego jawi się jako pewnego rodzaju paradoks, skoro ten wymiar ludzkiej egzystencji pozostaje tak blisko obszaru, którym zajmują się psychoterapeuci ${ }^{4}$.

Redukcjonizm psychologiczny sięga korzeniami czasów Zygmunta Freuda. Polegał na przekonaniu, że „doświadczenie duchowe może być w pełni wyjaśnione przez psychologię, a religię można traktować jako mechanizm nerwicowy (zarówno w wymiarze społecznym, jak i indywidualnym)"s. Równolegle do owego redukcjonizmu psychologicznego rozwijał się redukcjonizm teologiczny. Księża, niechętni psychoterapii w różnym stopniu, postrzegali ją jako swego rywala w pracy duszpasterskiej. Do tego klimatu nieufności wobec psychologii przyczyniało się także słabe przygotowanie kapłanów z zakresu tej dziedziny wiedzy.

Z końcem XX wieku owa odrębność teologii i psychologii przestała wystarczać, zwłaszcza tym, którym bliska była całościowa wizja człowieka. Duże znaczenie miało tu także posoborowe otwarcie Kościoła ${ }^{6}$. Obecnie stopniowo nurt wzajemnego słuchania się i zaciekawienia między teologią a psychologią zaczyna być silniejszy aniżeli obustronna wrogość i podejrzliwość. Dialog między obiema perspektywami spojrzenia na tajemnicę człowieka oraz wspólne wsłuchiwanie się w Boga coraz częściej bywają traktowane jako nieodzowne?

Niezbędną przesłanką dla integracji obu dyscyplin staje się potrzeba zwrotu antropologicznego w teologii oraz zwrotu teologicznego w antropologii. Te dwa zwroty pozwalają znaleźć prawdziwy punkt spotkania teologii z naukami szczegółowymi, z psychologią w szczególności. Tym miejscem styczności jest doświadczenie ludzkie, które ze swej natury jest otwarte na transcendencję. Ponadto zwrot antropologiczny teologii sprawia, że antropologia przestaje być tylko i wyłącznie jednym z działów teologii, a zamiast tego staje się cennym locus theologicus oraz uprzywilejowaną przestrzenią uprawiania teologicznej refleksji ${ }^{8}$.

${ }^{3}$ Gic, tamże.

${ }^{4}$ B. de Barbaro, Duchowość w psychoterapii - psychoterapia w duszpasterstwie, w: J. Griffith, M.E. Griffith, Odkrywanie duchowości w psychoterapii, Kraków 2008, s. 8-15.

${ }^{5}$ Tamże.

${ }^{6}$ Tamże

${ }^{7}$ T. Cantelmi, P. Laselva, S. Paluzzi, Dialog psychologii z teologia, Poznań 2006, s. 9-13. Psychologia na podstawie obserwacji zachowania osoby dociera do jej wewnętrznej psychodynamiki, która wyjaśnia to zachowanie. Procesy psychiczne mówią o czymś więcej niż tylko o samej sferze psychicznej człowieka, wskazują także na sferę ontologiczną, na tajemnicę osoby. Dlatego też badanie życia i działania jest również badaniem bytu człowieka. Stąd jako bezzasadne jawi się rozdzielanie teologii, która miałaby jako nauka aksjologiczno-normatywna odpowiadać na zasadnicze kwestie życia i śmierci, od psychologii, zadaniem której, jako nauki empiryczno-analitycznej, byłoby jedynie opisywanie akcydentalnych, dających się zaobserwować zjawisk. Por. tamże, s. 25.

${ }^{8}$ Tamże, s. 19. 
Specyfika i konieczność dialogu teologii chrześcijańskiej z psychologią ma swoje źródło w powiązaniu całej stworzonej rzeczywistości z Tajemnica Boga, która została objawiona w Jezusie Chrystusie, wcielonym Synu Bożym. W Nim natura boska i ludzka zamieszkały w jednej Osobie. Od-Boskie pochodzenie świata sprawia także, iż nauka i wiara nie są względem siebie konkurencyjne, ale wspomagają się na drodze odkrywania prawdy. Jak poucza Sobór Watykański II, istota badania metodycznego we wszystkich dziedzinach wiedzy, jeśli tylko przebiega ono w sposób prawdziwie naukowy i zgodny z normami moralnymi, nigdy nie będzie stać w opozycji wobec wiary, „sprawy bowiem świeckie i sprawy wiary wywodzą swój początek od tego samego Boga". Co więcej, kto wytrwale i w duchu pokory usiłuje zgłębiać tajniki rzeczywistości, ten, nawet będąc tego nieświadomym, jest niejako prowadzony ręką Boga, który podtrzymuje wszystkie rzeczy w istnieniu i sprawia, że są tym, czym są .

Jak zauważa włoski kapłan i psycholog, Amadeo Cencini, dialog teologiczno-psychologiczny nie powinien opierać się jedynie na relacji komplementarności, polegającej na tym, że jedna dyscyplina zaczyna swą działalność tam, gdzie kończą się kompetencje drugiej. Nie chodzi tu także o odgórnie założone dążenie do zgody i wzajemnego potwierdzenia psychologii i teologii. Celem jest tu co najwyżej poszukiwanie zbieżności, do której obie dziedziny dążą swoją specyficzną droga, posługując się własną metodologia, przy jednoczesnym obustronnym respektowaniu systemów pojęć właściwych każdej dziedzinie ${ }^{10}$.

Bruno Forte jest zdania, że teologia może zaoferować psychologii ostateczną perspektywę sensu mającą swe źródło w Bogu. Aby wypełnić to zadanie, teologia musi pozostać wierna swej najgłębszej tożsamości: „Jedynie taka teologia, która będzie ściśle i rygorystycznie «teologiczna», a zatem będzie miała na sercu Wiekuistego i będzie mówić o Bogu jako o wyłącznym Przedmiocie swego zainteresowania, uznając w Nim zarazem żywy Podmiot, przemawiający do niej poprzez słowo i milczenie, na które usiłuje odpowiedzieć, będzie mogła nawiązać autentyczny i znaczący dialog z psychologią opierającą się na wizji człowieka otwartej na Tajemnicę"11.

Taką właśnie teologią - $\mathrm{z}$ absolutnym prymatem Boga jako zasadniczą tezą - jest refleksja św. Jana od Krzyża. W myśl powyższego cytatu to właśnie znamię predysponuje ją do owocnej współpracy z psychologią. Wśród innych dzieł XVI-wiecznego mistyka Noc ciemna stanowi szczególnie nośny obszar dla dia$\operatorname{logu} \mathrm{z}$ psychologia. To graniczne doświadczenie ludzkiej egzystencji, jakim jest

\footnotetext{
${ }^{9}$ Sobór Watykański II, Konstytucja duszpasterska o Kościele w świecie wspótczesnym 36; por. T. Cantelmi, P. Laselva, S. Paluzzi, Dialog..., dz. cyt., s. 33.

${ }^{10}$ Tamże, s. 28

${ }^{11}$ B. Forte, Teologia e psicologia: resistenza, indifferenza, resa o integrazione?, w: Antropologia interdisciplinare e formazione, Bologna 1997, s. 75-95; cyt. za: T. Cantelmi, P. Laselva, S. Paluzzi, Dialog..., dz. cyt., s. 21.
} 
noc ciemna, ogarnia człowieka w całości jego bytu cielesno-psychiczno-duchowego. Obejmuje więc także ludzką psychikę, a przez nią oddziałuje również na sferę somatyczną.

\section{Zjawisko depresji}

Depresja jest szczególną raną, jaka może spotkać człowieka. Współcześnie coraz więcej ludzi cierpi z powodu tej choroby. Nasze społeczeństwo określa się nawet niekiedy mianem społeczeństwa depresyjnego ${ }^{12}$, zdaniem wielu filozofów, żyjemy w cywilizacji smutku ${ }^{13}$.

Depresja nosi w sobie pewien ból chaosu, do jej istoty należy wewnętrzna sprzeczność, rozbicie, zatarcie granic, nieład. Najprostsze rzeczy są dla cierpiącego człowieka nieznane, obce, dalekie. Wiele rzeczy prostych staje się trudnymi. W depresji człowiek jawi się jak bezradne dziecko. Im cięższa depresja, w tym bardziej odległa przeszłość, chory ucieka, cofając się do okresu dzieciństwa. W najcięższych postaciach depresji człowiek jest niczym niemowlę, całkowicie zdany na pomoc innych, a przy tym nadwrażliwy i podatny na najmniejsze zranienie. Świat w depresji staje się coraz bardziej zawężony, także przestrzennie - do jednego pokoju, do jednego fotela, łóżka ${ }^{14}$.

Jednym z ważnych rysów depresji jest również ogromne poczucie winy, dotyczące niemalże wszystkiego. W lżejszych formach depresji pojawiająca się agresja jest ukierunkowana bardziej na zewnątrz, natomiast w cięższej depresji człowiek bardziej oskarża samego siebie - cokolwiek by zrobił, czuje się winny ${ }^{15}$.

Antoni Kępiński, wybitny polski humanista, psychiatra, zagadnieniu depresji poświęcił jedną ze swoich książek. Jest to nie tylko specjalistyczna monografia, ale jednocześnie są to rozważania na temat ludzkiego smutku w ogóle, dlatego też opatrzona jest tytułem Melancholia. Pojęcie to znane już było Hipokratesowi (używa go także św. Jan od Krzyża), a - zdaniem Kępińskiego - termin ten lepiej odzwierciedla niektóre swoiście ludzkie aspekty tego, co dziś określane jest mianem „zespołu depresyjnego"16.

Autor Melancholii przedstawia bardzo szerokie spektrum opisywanego zagadnienia: rozpoczynając od depresji endogennej (o źródłach wewnętrznych, w przeciwieństwie do depresji egzogennej - pochodzenia zewnętrznego), poprzez depresję przełomów biologicznych (w tym: depresję inwolucyjna, wieku młodzieńczego, poporodowa), depresje objawowe (np. depresje występujące po cho-

\footnotetext{
${ }^{12}$ Por. K. Grzywocz, Ból ludzkich zranień i potrzeba przebaczenia, konferencje wygłoszone w Centrum Duchowym Salwatorianów w Krakowie.

${ }^{13}$ J. Catalan, Depresja a życie duchowe, Kraków 2007, s. 5.

${ }^{14} \mathrm{~K}$. Grzywocz, Ból ludzkich zranień..., dz. cyt.

15 Tamże.

${ }^{16}$ A. Kępiński, Melancholia, Kraków 1993, s. 7.
} 
robach zakaźnych, w zaburzeniach hormonalnych), depresje organiczne (np. mogą być one pierwszym zwiastunem uszkodzenia ośrodkowego układu nerwowego), depresje starcze, depresję schizofreniczna, depresje nerwicowe, depresje w psychopatiach, omawia także depresję z wyczerpania, depresję szczytu (występuje w momencie, gdy po wielu latach zmagania i wielkiego napięcia człowiek wreszcie osiagnął wymarzony cel), depresję reaktywną (będącą reakcją na jakieś wydarzenie - np. utratę ukochanej osoby) czy też depresję cywilizacyjna (,smutek urzeczywistnionej baśni”, gdy ziściły się najśmielsze marzenia ludzkości, a mimo to człowiek odczuwa smutek i niezadowolenie, tęskni za prostszymi formami życia).

Kępiński stara się przybliżyć świat przeżyć osoby dotkniętej melancholią. Smutek depresji ogarnia człowieka niczym ciemność, świat traci kolory. Normalna energia życiowa zanika, każda decyzja sprawia niezmierny problem, błahe dotychczas sprawy urastają do rangi dużych problemów. W ciemności zaczyna dominować chaos, człowiek gubi się, nie wie, co wybrać, w którą stronę się zwrócić. Spadek dynamiki życiowej dotyczy zarówno czynności psychicznych, jak i fizycznych. Wszystko podlega inercji, porusza się z trudem. Rzeczywistość zdaje się czymś wrogim, pojawia się wobec niej poczucie bezsilności. Spowolnienie ruchowe w depresji może niekiedy przechodzić w stupor - chory tkwi wówczas przez długi czas w jednej pozycji. Rzadziej pojawia się niepokój ruchowy i płacz. W cięższych depresjach na ogół chory nie może płakać, choć często pragnie tego, aby poprzez łzy uzewnętrznić swój smutek ${ }^{17}$.

\section{Symbol nocy}

Przyjrzyjmy się teraz nocy ciemnej. Zaczniemy od krótkiego nakreślenia symboliki nocy. Noc rozumiana jako część doby niejako wchodzi w nasze wnętrze i działa w nas podobnie jak to, co Jan nazwał nocą w znaczeniu przenośnym. Albo odwrotnie - to właśnie, co powoduje w nas skutki podobne do nocy kosmicznej, nazywa się nocą w znaczeniu przenośnym. Światło dnia, oświetlając rzeczy, ukazuje ich właściwości dostrzegalne wzrokiem. Natomiast noc pochłania je i zamazuje ich kształty. To, co się w niej zatopi, nie przestaje wprawdzie istnieć, jednak staje się niewidzialne, nieokreślone jak sama noc, albo też ocienione, mroczne, groźne. Noc ogranicza możliwości używania wzroku, hamuje nasze ruchy. Po całym dniu, nocą mamy mniej sił niż za dnia, pora nocna może też niekiedy sprzyjać odczuwaniu samotności. Bywa przeżywana jako przedsmak śmierci ${ }^{18}$.

Obok nocy ciemnej i przejmującej grozą istnieje także drugie, odmienne oblicze nocy. Może być to noc skąpana w poświacie księżyca, roziskrzona gwiaz-

\footnotetext{
${ }^{17}$ Tamże, s. 7-9.

${ }^{18}$ E. Stein, Wiedza Krzyża. Studium o św. Janie od Krzyża, Kraków 1994, s. 52.
} 
dami, rozjaśniona miłym, łagodnym światłem. Taka noc nie pochłania rzeczy, pozwala za to dostrzec ich nocne oblicze. Ostre kształty rzeczy widziane za dnia teraz stają się przyciemnione, delikatniejsze. Noc ukazuje takie zarysy kształtów, jakich nie ujawnia światło dnia. Milknie gwar, ustaje pośpiech, dają się słyszeć głosy, które giną wśród dziennego hałasu. Noc przynosi ze sobą uciszenie i spokój, które przelewają się także w duszę człowieka. Jak zauważa Edyta Stein, „,istnieje nocna, łagodna jasność ducha, kiedy dusza wolna od służby i zajęć wiążących ją za dnia, swobodna i skupiona zarazem, wnika w głębię powiązań swej własnej istoty i życia, świata i nadświata. I znajduje wielkie, dobroczynne uciszenie w pokoju takiej nocy"19.

Jan od Krzyża jest nazywany niekiedy Doktorem Nocy, choć niektórzy z badaczy jego pism uważają że równie słusznie należy mu się tytuł Doktora Świa$\mathrm{tła}^{20}$, czy też Doktora Miłości Bożej ${ }^{21}$. Bez wątpienia jednak symbol nocy stanowi jedną z najbardziej oryginalnych intuicji twórczych Jana od Krzyża ${ }^{22}$. Realistyczne odniesienie nocy kosmicznej do doświadczenia ciemności duchowych stanowi o sile tego symbolu, który posiada charakter duchowy i literacki zarazem $^{23}$.

\section{Noche oscura}

Stan osoby poddanej nocy ciemnej przedstawia się podobnie jak wyżej opisany stan depresji: dusza „nie może uwierzyć, że Bóg ją kocha i że ona na tę miłość zasługuje. Przeciwnie, widzi, że zasługuje na odrzucenie nie tylko przez Boga, ale przez wszystkie stworzenia i to na zawsze" (NC II, 7, 7). Ciemność depresji wnika także w sumienie. Człowiek nie jest w stanie ocenić swoich czynów, nie potrafi dokonać jasnej oceny moralnej ${ }^{24}$. Nasuwa się tu pewna analogia z cierpieniem spowodowanym przez „ducha przewrotności”, które Jan od Krzyża opisuje w pierwszej księdze Nocy ciemnej. Duch ten zaciemnia zmysły i rozpoznanie człowieka „do tego stopnia, że nabawia duszę tysięcznych skrupułów i powikłań”. Zaćmiewa

${ }^{19}$ Tamże, s. 53.

${ }^{20}$ O. Filek, Wprowadzenie do dziet św. Jana od Krzyża, w: Jan od Krzyża, Dzieła, Kraków 2010, s. 47.

${ }^{21}$ N. Cummins, Wprowadzenie do nauki św. Jana od Krzyża, tłum. T. Kieniewicz, Kraków 2012, s. 5.

${ }^{22}$ Korzenie symbolu nocy w dziełach św. Jana od Krzyża prócz doświadczenia nocy kosmicznej oraz doświadczenia ciemności i opuszczenia, które staje się udziałem Świętego w toledańskim karcerze sięgają także tradycji biblijnej i patrystycznej mówiącej o tym, że udzielanie się transcendentnego Boga śmiertelnemu człowiekowi dokonuje się w ciemności (por. J. Gogola, Wprowadzenie, w: Jan od Krzyża, Dzieła, Kraków 2010, s. 493).

${ }^{23}$ J. Gogola, Wprowadzenie..., dz. cyt., s. 492.

${ }^{24}$ Tamże. 
także umysł człowieka tak, że nic nie może mu przynieść ukojenia ani nie może oprzeć sądu na zdaniu czy radzie innych (por. NC I, 14, 3).

Z kolei na początku NC II, 8 hiszpański mistyk, omawiając ów symptom nocy ciemnej, jakim jest niemożność wzniesienia do Boga uczuć ani umysłu, zaznacza także, iż dusza ,nie mniej jest bezradna w sprawach doczesnych. Popada czasem $\mathrm{w}$ takie zamroczenie i w taką niepamięć o wszystkim, że czas upływa, a ona nie zdaje sobie sprawy, co czyniła, co myślała, co czyni lub co ma czynić. I nie może, choćby chciała, przywołać uwagi do tych spraw" (NC II, 8, 1).

Święty Jan od Krzyża nie zajmuje się wprost problemem psychologii rozwoju i towarzyszących mu kryzysów. Jego zasadniczym celem jest wskazanie właściwego kierunku osobie wchodzącej w życie mistyczne. Gdy święty pisarz wspomina sensu stricte o depresji (melancholii), czyni to jedynie pobocznie ${ }^{25}$. Jednak procesu przyspieszonego rozwoju duchowego, jakiemu podlega osoba doświadczająca nocy ciemnej, nie można zredukować do samej teologii ani też nie można go psychologizować, czego świadom jest sam autor omawianego dzieła. Człowiek jest całością ciała, duszy i ducha, a jego poszczególne sfery wzajemnie się przenikają i splatają. Oczyszczające i uświęcające działanie Ducha Bożego powoduje zaburzenie, a w dalszej kolejności przetworzenie ludzkich struktur psychiczno-duchowych. To wszystko nie pozostaje bez wpływu na zdrowie psychiczne (a także fizyczne) człowieka ${ }^{26}$.

Istnieje wielce prawdopodobna hipoteza, że św. Jan od Krzyża w Nocy ciemnej opisuje swoje własne przeżycia, w tym także głęboką depresję, która wybrzmiała szczególnie wyraźnie w czasie uwięzienia w toledańskim karcerze ${ }^{27}$. Także zawartość treściowa, formalna i grafologiczna rękopisów Doktora Karmelu wskazuje na pewne oznaki istnienia osobowości depresyjnej u hiszpańskiego poety. Analizując terminologię stosowaną przez św. Jana, można zobaczyć, iż początkowe stany mistyczne w swym opisie przypominają stany melancholii, co skłania samego mistyka do wprowadzenia pewnych kryteriów, które określałyby podobieństwa i różnice pomiędzy chorobą a działaniem Boga ${ }^{28}$. Autor Nocy ciemnej nie wyklucza także współistnienia obu rzeczywistości (por. NC I, 3, 4).

Termin melancholia pojawia się m.in. w NC I, 4. Ten rozdział traktuje „o innych niedoskonałościach, które popełniają początkujący pod wpływem trzeciej wady głównej, którą jest nieczystość". W tym rozdziale znajduje się pewien passus bardzo interesujący ze względu na pojawiające się w nim stwierdzenie, iż noc ciemna jest stanem jeszcze cięższym niż sama melancholia: „Pokusy te oddzia-

${ }^{25}$ J. Skawroń, Noc ducha i dezintegracja pozytywna, Kraków 2007, s. 240.

${ }^{26}$ Tamże, s. 231.

${ }^{27} \mathrm{~J}$. Alvarez w książce Mistica y depresión nadzwyczajną znajomość i przenikliwą diagnozę krańcowych stanów ducha zawartą na kartach Nocy ciemnej uzasadnia osobistym doświadczeniem życiowym św. Jana. Por. J. Skawroń, Noc ducha..., dz. cyt., s. 258.

${ }^{28}$ Tamże, s. $240 \mathrm{n}$. 
łują z taką siłą i tak często na osoby, zwłaszcza melancholiczne, że aż litość bierze patrzeć na ich udręczone życie. Udręczenie to w chwilach przypływu melancholii na takie osoby urasta do tego stopnia, iż sądza, że są nagabywane przez szatana i nie mają możności uwolnienia się od niego, chociaż niektóre z wielkim wysiłkiem i trudem zdołają się uwolnić od takiego nagabywania" (NC I, 4, 3). Przeważnie jednak, w przypadku, gdy owe nieczyste pokusy powstają na podłożu melancholii, trudno je zwalczyć, nie uleczywszy najpierw chorobliwego stanu człowieka, „chyba że dusza wejdzie w noc ciemną i ta powoli pozbawi ją wszystkiego" (tamże). W powyższym opisie uwidoczniony jest pasywny charakter zarówno melancholii, jak i nocy ciemnej. Sama noc intensyfikuje symptomy melancholii ${ }^{29}$.

W pierwszych dziesięciu rozdziałach drugiej księgi Nocy ciemnej szczególnie wyraźnie widzimy, jak Doktor Karmelu dba o to, aby odróżnić dynamizm rozwojowy nocy zmysłów i ducha od stanów chorobowych ${ }^{30}$. Takie rozgraniczenie nie wyklucza bynajmniej, iż te ostatnie mogą stanowić jeden z elementów nocy ciemnej. Procesu duchowego wzrastania prowadzącego do zjednoczenia z Bogiem nie można w całości utożsamić z jednostką chorobową, chociaż choroba może stanowić także jeden z jego aspektów. Wówczas także ona zostaje poddana Bożej logice działania i w dalszej perspektywie również służy osiagnięciu celu - zjednoczeniu z Bogiem. Choroba nie stanowi przeszkody dla działania Boga zmierzającego do uchrystusowienia człowieka: „Oschłość związana z nocą ciemną niesie z sobą zwyczajnie troskę wraz z bolesną obawą, że [...] nie służy się Bogu. A chociaż niekiedy ta oczyszczająca oschłość może być połączona z melancholią albo z inną niedyspozycją, to jednak nie przestaje dlatego oczyszczać pożądania, ponieważ to pożądanie zostaje oczyszczone $\mathrm{z}$ wszelkiego upodobania i zwraca całą troskę ku Bogu" (NC I, 9, 3).

\section{Stanowiska znawców}

Trudno byłoby zaprzeczyć, że istnieje pewne podobieństwo między nocą bierną ducha a depresją. J. Alvarez w swoim dziele Mistica y depresión prezentuje poglądy czterech autorów dotyczące tego tematu ${ }^{31}$. W. James reprezentuje stanowisko utożsamiające zjawisko biernej nocy ducha z depresją. H. Delacroix uważa, że stany nocy ducha i depresji mogą współwystępować. W rozwoju życia mistycznego wyróżnia on etap wielkiej gorliwości, podczas którego mogą (choć nie muszą) pojawić się pewne mistyczne zjawiska takie jak ekstazy, wizje, słowa nadprzyrodzone. Człowiek w tym okresie życia mistycznego opływa w duchową

\footnotetext{
${ }^{29}$ Tamże, s. 243.

${ }^{30}$ Tamże, s. 244.

${ }^{31}$ Tamże, s. 241.
} 
rozkosz. Jest to etap niedoskonałej kontemplacji początkowej, w czasie którego w duszy ludzkiej obecne są liczne ukryte wady, a wśród nich egoizm. Aby pójść krok dalej, konieczne jest głębsze oczyszczenie, podczas którego mistyk poznaje swą moralną, ale i ontyczną słabość i niemoc. Rozpoczyna się czas pasywnej nocy ducha, na którą składają się intensywne cierpienia o zabarwieniu neurotycznym, melancholia, ciężka depresja. Te udręki przeplatane są okresami rozradowania i uszczęśliwienia.

Laigner-Levastine, psychiatra, optuje również za odczytaniem nocy ducha jako przenikania się stanów chorobowych i nadprzyrodzonych. Trzy znaki przejścia od medytacji do kontemplacji, jakie podaje św. Jan, interpretuje jako symptomy mogące towarzyszyć także depresji. Dla potwierdzenia swej argumentacji powołuje się na Taulera, który potwierdza, że ten, kto chciałby zjednoczyć się z Bogiem, powinien być gotów na cierpienia duchowe i psychiczne.

M. Mardon-Robinson również bada noc ciemną od strony psychiatrii i opowiada się za uznaniem depresji za komponent nocy. Stwierdza, że można odnaleźć wiele podobieństw między sanjuanistyczną nocą a depresją melancholiczną. Wyodrębnia i porównuje liczne przebiegi psychiczne obu fenomenów, dochodząc do wniosku, że mają wiele elementów wspólnych. Są to: smutek, zaniepokojenie, poczucie beznadziejności, odkładający się w pamięci ciężar przeszłości, doświadczenie pustki i próżni.

\section{Sens depresji}

Można zastanawiać się, czy to bolesne doświadczenie, którym jest depresja, kryje w sobie jakiś sens. Dla duńskiego filozofa, S. Kierkegaarda depresja była początkiem jego filozofii. Osobiste doświadczenie cierpienia i choroby uczynił on punktem wyjścia swoich rozważań o człowieku, które doprowadziły go do głębokiej więzi z Bogiem. „Depresja musi mieć swoje znaczenie” - pisał Romano Guardini, jeden z największych współczesnych teologów, mistyków, sam cierpiący na depresję ${ }^{32}$.

Wiara daje człowiekowi przekonanie, że Bóg jest obecny w każdej chwili jego życia. Gdyby bowiem Ten, który podtrzymuje wszystko w istnieniu, opuścił jakiś moment ludzkiej egzystencji, wówczas tej chwili by nie było. Jeśli zatem Bóg jest zawsze obecny, to znaczy, że każda sekunda ludzkiego życia niesie w sobie boski sens. Boża miłość jest także blisko ludzi pogrążonych w depresji ${ }^{33}$. Ten, który nie złamie nadłamanej trzciny ani nie zgasi tlącego się knotka świecy (por. Iz 42,3), nie opuszcza ludzki tak głęboko zranionych. A więc, dzięki Bożej obecności, również to wszystko, co dzieje się w depresji, naznaczone jest sensem.

\footnotetext{
${ }^{32}$ Zdarzało się, że wskutek choroby był do tego stopnia przelękniony i roztrzęsiony, że uczniowie musieli prowadzić go na wykłady. Por. K. Grzywocz, Ból ludzkich zranień..., dz. cyt.

${ }^{33}$ Tamże.
} 


\section{Teoria dezintegracji pozytywnej i noc ciemna}

Wspólnym ogniwem, które może połączyć noc ciemną z doświadczeniem jakiejś psychicznej niespójności, jest aspekt pozytywny, w którym możemy rozpatrywać oba fenomeny. Wbrew pozorom bowiem ciemna noc psyche może przynieść temu, kto jej doświadcza, niespodziewane życiodajne owoce.

Dla zrozumienia sanjuanistycznej nocy ducha oraz powiązań, jakie istnieją między nią a depresją przydatne może być nakreślenie zasadniczych rysów teorii pozytywnej dezintegracji. Jej twórcą jest prof. Kazimierz Dąbrowski (1902-1980), światowej sławy psychiatra i psycholog. Według teorii dezintegracji pozytywnej warunkiem rozwoju osobowości jest rozpad, czyli dezintegracja, pierwotnej struktury psychicznej. Poprzez wewnętrzne konflikty, poszukiwania i akty wyboru dochodzi do integracji psychiki na wyższym poziomie ${ }^{34}$. W tym kontekście polski humanista rozpatruje wiele zaburzeń psychicznych, zwłaszcza typu nerwicowego. Jego zdaniem, często są one nie tyle chorobą, ile raczej przejawem pozytywnego kryzysu rozwojowego. Takie spojrzenie wynika z podstawowej tezy, jaką przyjął Dąbrowski - mianowicie zdrowie psychiczne wiązał on nie z przystosowaniem, ale z rozwojem i jego dynamiką ${ }^{35}$.

Teoria dezintegracji pozytywnej stanowi pierwszą usystematyzowaną próbę ukazania osobowości rozwijającej się ku ideałowi przez przekraczanie kolejnych poziomów (a nie tylko faz) ${ }^{36}$. Jest to optyka wielozakresowa, Dąbrowski postrzega rozwój nie tylko w jego wymiarze horyzontalnym, ale równocześnie w jego dymensji wertykalnej. Zdaniem wybitnego psychiatry, tym, co warunkuje rozwój, jest osobowościowa struktura wielopoziomowa, powiązana treściowo z myśleniem, odczuwaniem, wyobraźnią i intuicją ${ }^{37}$.

Wbrew opiniom oceniającym psychonerwice jako zjawisko negatywne, Dąbrowski dostrzega w nich pozytywne odniesienia rozwojowe. Wyróżniki tego stanu, jak na przykład wzmożona pobudliwość emocjonalna i intelektualna, moga być wyrazem bardziej intensywnego rozwoju. $Z$ jednej strony osoba doświadcza cierpienia, konfliktów, lęku, smutku, a z drugiej z przeżyciami tymi wiąże się napięcie, które towarzyszy rozwojowi i stanowi pewnego rodzaju twórczą dramaturgię $e^{38}$.

\footnotetext{
${ }^{34}$ Osobowość rozumie Dąbrowski jako rezultat „obiektywizacji funkcji uczuciowych i popędowych oraz obiektywizacji wartości duchowych, produkt przebycia okresu trudności, niepokoju, kryzysów, zahamowań, smutku i depresji, obsesji, stanów lękowych i większości psychonerwic na wyższym poziomie" (K. Dąbrowski, Dezintegracja pozytywna, Warszawa 1979, s. 35).

${ }^{35}$ J. Skawroń, Noc ciemna..., dz. cyt., s. 7.

${ }^{36}$ Tamże, s. 174.

${ }^{37}$ Według teorii dezintegracji pozytywnej rozwój „fazowy” może być ujęty w ramy statystyczne, natomiast „poziom rozwoju” stanowi normę osobową i zindywidualizowaną. Por. tamże, s. 181.

${ }^{38}$ Tamże, s. 246.
} 
Profesor Dąbrowski czyni rozróżnienie między nerwicą a psychonerwicą ${ }^{39}$. Polski psychiatra uważa, że przyczyna nerwic tkwi w nieprawidłowym funkcjonowaniu narządów lub układów, które wpływają na psychikę, choć nie można wskazać jednoznacznie żadnej strukturalnej i leżącej w konkretnym organie przyczyny nerwicy. Charakterystyczna jest tu dominanta procesów somatycznych. Natomiast psychonerwice byłyby to zaburzenia uczuciowo-dążeniowe oddziałujące na sferę wegetatywną. W psychonerwicach osoba doświadcza ambiwalencji uczuciowej (naprzemiennej pobudliwości i depresji), uwrażliwienia na sprawy innych, konfliktów wewnętrznych. Psychonerwice powstają wskutek wewnętrznej stagnacji, wejścia w ślepy tor na drodze rozwoju osobowego. Jest to zaburzenie pewnej funkcji psychicznej, które stoi przed możliwością przekształcenia tej funkcji dla wyższej, rozwojowej formy działania. W przeciwieństwie do nerwicy obecna jest tu zdolność osoby do hierarchizacji i refleksyjności. Nie jest to forma somatyczna, a raczej mentalna i konceptualna. Dąbrowski zaznacza wszakże, że w przypadku psychonerwicy przyczyna cierpienia może stanowić zagadkę ${ }^{40}$.

W świetle myśli Kazimierza Dąbrowskiego depresja nie musi być więc postrzegana jako zjawisko negatywne. Im większe ciążenie ku dezintegracji, tym większa winna pojawić się siła przeciwstawiająca się jej, owocująca nową jakością życia do tego stopnia, że depresja może zatracić swój niszczycielski i chorobliwy charakter. Własna słabość i ułomność osoby cierpiącej na depresję moga stać się „windą” wynoszącą ją na szczyty człowieczeństwa. Jedynie egoizm i samowystarczalność są tym, co zatrzymuje osobę na pewnym rejestrze rozwo$\mathrm{ju}^{41}$. Zdaniem Dąbrowskiego, stany depresji nie są wyłącznie wynikiem egocentryzmu, hipochondrii czy własnych trudności, ale bywają niekiedy „depresjami społecznymi”, które powstają na tle współprzeżywania dramatów i smutków innych ludzi ${ }^{42}$.

Kto, akceptując swoją bezradność, pragnie jednocześnie tego, co wydaje się nieosiagalne, wzniesie się ku temu, co wcześniej jawiło się jako niemożliwe, jeśli tylko przyjmie za przewodniczkę logikę wiary. Mistycy przeżywali swoje cierpienie ze świadomością włączenia ich w dialektykę śmierci i zmartwychwstania Chrystusa. Podobna perspektywa otwiera się przed człowiekiem pogrążonym w depresji z jej kryzysami, zahamowaniami czy też smutkiem obsesji, jeśli umieści swoją sytuację egzystencjalną w przestrzeni nadprzyrodzonej wiary ${ }^{43}$.

${ }^{39}$ Powszechnie jednak używa się terminu nerwica, gdyż ów drugi termin sugeruje bliskość psychozy. Tamże, s. 179 (przypis 5).

${ }^{40}$ Tamże, s. $179 \mathrm{n}$.

${ }^{41}$ Tamże, s. 176.

${ }^{42}$ K. Dąbrowski, Dezintegracja..., dz. cyt., s. 79.

${ }^{43}$ Tamże. 


\section{Pozytywny aspekt depresji}

Niektórzy psychiatrzy stwierdzają, że nie jesteśmy w stanie z naukową precyzją powiedzieć, skąd dokładnie bierze się depresja. Wśród tych z nich, którzy są ludźmi wierzącymi, wielu skłonnych jest uznać za prawdziwe twierdzenie, że depresja zawiera w sobie pewien element tajemniczy i zarazem proroczy. Według R. Guardiniego depresja sięga swym początkiem grzechu pierworodnego, jej źródeł należy doszukiwać się w utracie pierwotnej więzi z Bogiem. Dlatego ludzie depresyjni są prorokami naszych czasów. Ich doświadczenie mówi nam, że istnieje coś więcej niż człowiek i otaczająca go ziemska rzeczywistość. W bólu, smutku, lęku tych osób ukazuje się świat, o istnieniu którego nieraz zbyt szybko się zapomina. Są jakby głosem wołającym, że życie bez Boga jest ułudą, że bez Boga możliwa jest tylko śmierć ${ }^{44}$. Ich przesłanie niekiedy mówi bardziej o otchłani i stracie cudzej, a nie własnej. Bywa, że cierpienie ludzi pogrążonych w depresji jest wynikiem niesienia pustki innych, czyjegoś, nieraz zawinionego smutku, większego niż źródło radości ${ }^{45}$. Dlatego tym doświadczeniem Bóg obdarza tych, o których wie, że są zdolni ów ciężar unieść, wie, że Mu nie odmówią i że może zaufać ich miłości do Niego.

U obu autorów - zarówno u św. Jana od Krzyża, jak i u Kazimierza Dąbrowskiego - obecny jest aksjomat o konieczności przejścia przez czas dezintegracji, rozbicia, okresowej nierównowagi, podążania drogą rozwoju (lub uświęcenia, uchrystusowienia) ku ideałowi osobowemu. Aby dojść do upragnionego celu, nieuniknione jest przejście przez to, co powoduje utrapienie i ból, przez coś, czego człowiek do końca nie rozumie ${ }^{46}$.

\section{Synteza teologiczno-psychologiczna}

W świetle tego, co dotychczas zostało powiedziane, spróbujemy zebrać i spuentować powyższe wnioski dotyczące wzajemnych powiązań między nocą ciemną a depresją lub innymi zaburzeniami psychicznymi.

Symptomy depresji wykazują pewne podobieństwa do cech nocy ciemnej opisanej przez karmelitańskiego mistyka. Może ona objawiać się: apatycznym nastrojem, poczuciem beznadziejności, spowolnieniem ruchowym, rozmyślaniem o śmierci, brakiem poczucia własnej wartości, natrętnym i nieproporcjonalnym obwinianiem siebie, samopotępieniem. Ten stan różni się jakościowo od okreso-

${ }^{44} \mathrm{~K}$. Grzywocz, Ból ludzkich zranień... dz. cyt.

${ }^{45}$ Tamże.

${ }^{46}$ K. Dąbrowski nawiązuje do określenia Karla Jaspersa ,„pasja nocy”, które jest obrazem udręczenia, samotności, przeżywania bezsensu życia, stanów lękowych i depresyjnych. Według niemieckiego egzystencjalisty próby ich przezwyciężenia są szansą wejścia do „normy dnia” (K. Dąbrowski, Dezintegracja..., dz. cyt., s. 84). 
wego smutku po stracie lub złego nastroju, gdy znana jest jego przyczyna. Ma globalny charakter, ogarniający całą osobę. Składają się nań zespoły depresyjne, lękowe i obsesyjne. Jest to stan o zmieniających się fazach - przygnębienie, wycofanie się i pesymizm przeplatają się z okresami rozradowania czy wręcz euforii połączonymi niekiedy z wysoką samooceną.

Jan od Krzyża tak opisuje noc ciemną: ,jest to wpływ Boga na duszę, oczyszczającego ją z nieświadomości i niedoskonałości habitualnych, naturalnych i duchowych. Wpływ ten ludzie duchowi nazywają kontemplacją wlaną albo teologia mistyczna. W tej kontemplacji poucza Bóg duszę sposobem ukrytym i zaprawia ją do doskonałej miłości, podczas gdy ona nic nie czyni i nie rozumie, jakim sposobem owa kontemplacja jest wlewana" (NC II, 5, 1). W noc ducha nie można wejść mocą własnej decyzji. To Bóg jest Tym, który wprowadza i przeprowadza duszę przez noc ku światłu i wolności. On także określa i ustanawia czas trwania poszczególnych okresów światła i ciemności, pocieszenia i strapienia ${ }^{47}$.

Owocem nocy ducha jest odnowiona wiara, nadzieja i miłość. Wiara - dla której każde wydarzenie życia, zarówno smutne, jak i radosne, jest sakramentem niosącym Boga; nadzieja - cała złożona jedynie w Bogu, niezmienna i stabilna w obliczu największych nawet przeciwności; wreszcie miłość - potężniejsza niż śmierć.

Ten, kogo Bóg przeprowadził przez noc ciemna, poznał szerokość, głębokość, długość i wysokość Bożej miłości. Pomny na to, że Bóg wyprowadził go niejako z krainy umarłych, spodziewa się od Boga wszystkiego. Podobnie jak św. Paweł jest pewien, że nic nie zdoła odłączyć go od miłości Jezusa Chrystusa. Bóg poprzez noc ciemną objawił mu bowiem bezmiar swojej dobroci. Dlatego wie, że ani to, co wysokie, ani to, co głębokie, ani przeszłość ani przyszłość, ani żadna inna moc nie oddzieli go od Boga (por. Rz 8,38n). To, co wcześniej niosło w sobie zarzewie śmierci, teraz eksploduje nowym życiem. To samo doświadczenie nocy ciemnej, które wcześniej - wydawało się - negowało istnienie Wszechmocnej Miłości, teraz zaowocowało w duszy niezachwianą pewnością Bożej opieki, napełniając ją odwagą i śmiałością.

W doczesnym życiu wszystko ma swój kres. Także noc ciemna. Gdy po przebyciu tej drogi, jaką jest noc, patrzy się wstecz, dostrzega się pewną skończoność, przemijalność jej etapów, stadiów i tego wszystkiego, co się na nią składało. Ogień ciemnej nocy wypalił wszystko, pozostawiając sam diament miłości, który już wcześniej był ukryty wśród nocnych ciemności, a teraz jaśnieje swym blaskiem w pełni. Gdy przeminęły już udręki nocy, w brzasku nowego dnia człowiek kontempluje miłość - ów bezcenny dar, który z naddatkiem wynagradza bolesne godziny minionych cierpień. $\mathrm{Z}$ poszerzonego cierpieniem ludzkiego serca wznosi się ku Bogu dziękczynienie za łaskę ciemnej nocy.

\footnotetext{
${ }^{47}$ Tamże, s. 247.
} 
W kontekście zaburzeń natury psychicznej przejawem nocy jest głęboki smutek, przez który nie może się przebić promień słońca. W gęstniejącej mgle nikną barwy, formy i kształty, w jakie ujęte było dotychczasowe życie człowieka. Te psychiczne procesy mają swoje źródła w wewnętrznej głębi osoby, skąd biorą początek korzenie wszystkich jej dynamizmów ${ }^{48}$. Zarówno depresja, jak i noc ciemna mogą stać się drogą z ciemności do światła, ze śmierci do życia.

Dla pytania, czy problematykę depresji należy ujmować w kategorii losu, czy też łaski decydująca jest kategoria wiary. Los niesie z sobą pewną niezrozumiałość, nieuchronność. Tworzy się dystans między człowiekiem a całością jego egzystencjalnego doświadczenia, które przedstawia się jako złowieszcze fatum bawiące się człowiekiem. Wobec ,ślepego losu” człowiek pozostaje bez opieki, pozbawiony jakiegokolwiek wpływu na bieg wydarzeń, skazany na nieprzewidywalne igraszki ludzkiej doli. Wobec cierpienia człowiek postrzegający swoje życie przez pryzmat losu wchodzi w sfere głuchej rozpaczy i beznadziei ${ }^{49}$. Z kolei dla człowieka obdarzonego wiarą łaska przenika wszystkie obszary jego egzystencji, dostrzega we wszystkich wydarzeniach swego życia obecność miłującej ręki Opatrzności. A zatem wszelkie cierpienia, również te, które składają się na noc ciemna, nie stanowią dla niego przekleństwa.

O tym, jak istotne novum wnosi wiara w ludzkie przeżywanie cierpienia i jak jest ona znacząca dla postawy przyjętej wobec tego doświadczenia, mówi o. Romulo Londoño, wicedyrektor Międzynarodowego Centrum Terezjańsko-Sanjuanistycznego w Ávila: „Bóg udziela owej łaski [nocy ciemnej - przyp. P.H.] w przeróżnych okolicznościach, posługując się bardzo różnymi sposobami. Musimy tu jeszcze dodać, iż «nie odpoczywa ani nie śpi Ten, który czuwa nad Izraelem». Dlatego też wszystkie okoliczności, sytuacje i wydarzenia są podatne na działanie Boga. Można wręcz powiedzieć, że ponieważ Bóg jest zawsze z nami, żadne wydarzenie naszego życia nie jest $\mathrm{Mu}$ obce. I pamiętać musimy, iż On nieustannie jest uważny, by udzielać nam tego, czego najbardziej potrzebujemy według naszego osobistego rytmu. Wszystko zależy od osobistej otwartości i dyspozycyjności wobec sytuacji teologalnie trudnych, od otwartości na to, by przeżywać je na sposób Boży"50.

Ciemna noc ducha, jak również cierpienie wpisujące się w dezintegrację pozytywną, zmierzają ku temu, aby przygotować i skłonić człowieka do przyjęcia nowej, pełnej i prawdziwej formy ducha - zjednoczenia w miłości z Bogiem bądź też osiagnięcia pewnego osobowego ideału ${ }^{51}$. Czas zamętu tożsamościowego jako znamię przynależne zarówno nocy ducha, jak i niektórym zaburzeniom psychicznym może być początkiem procesu chrystoformizacji osoby ludzkiej, kształto-

\footnotetext{
${ }^{48}$ J. Skawroń, Noc ducha..., dz. cyt., s. 249.

49 Tamże, s. 245.

${ }^{50}$ „Głos Karmelu” 20(2008) nr 2, s. 22-24.

${ }^{51}$ J. Skawroń, Noc ducha..., dz. cyt., s. 334.
} 
wania się nowej tożsamości - na wzór Syna Bożego. Noc ciemna czy też choroba mogą być czasem walki duchowej, zwieńczonej błogosławieństwem nowego imienia (por. Rdz 32,29) ${ }^{52}$.

Doktor Karmelu pokazuje nam, że nic nie jest w stanie odłączyć nas od miłości Chrystusa, nawet to, co tylko z ludzkiego punktu widzenia wydawałoby się przegrana, nawet najcięższa niemoc psychiki, a wręcz odwrotnie - owo cierpienie może stać się dźwignią wynoszącą nas ku Niemu, gdyż „we wszystkim tym odnosimy pełne zwycięstwo, mocą Tego, który nas umiłował", ponieważ z tymi, którzy Go miłują, Bóg współdziała we wszystkim dla ich dobra (por. Rz 8,37.28).

W każdym stadium duchowego rozwoju, także w czasie nocy biernej zmysłów i ducha przepływa w człowieku strumień Bożej miłości. Dusza wraz ze wszystkimi swoimi władzami jest pogrążona w ciemnościach. Jednak właśnie będąc $\mathrm{w}$ owym stanie swego rodzaju nieświadomości, poznaje Boga lepiej niż kiedykolwiek, gdyż ponad, a w pewien sposób także we wszystkim tym, co przeżywa, przez gęste chmury przenika blask Tajemnicy.

Bóg przez misterium nocy ciemnej wprowadza człowieka w misterium paschalne Swego Syna, Jezusa Chrystusa. Noc zmysłów i ducha jest bez wątpienia wkroczeniem w paschalną przestrzeń szkoły cierpienia. Już samo wejście w noc jest możliwe dzięki „mocy i gorącości” miłości duszy do Oblubieńca (por. NC I Prolog, 2). Bez uczestnictwa w męce, śmierci i zmartwychwstaniu Chrystusa niemożliwe jest unio mistica z Bogiem, a miłość byłaby tyko zafałszowaniem miłości ${ }^{33}$.

$* * *$

Przy końcu powyższych rozważań należy wrócić do pytań postawionych na początku, dotyczących relacji, w jakiej pozostają depresja i mistyczna noc ciemna. Osoba postronna, kierując się jedynie zasadami empirii, może dostrzec w konkretnym ludzkim doświadczeniu tylko i wyłącznie ciężką depresję z jej wzlotami i upadkami, fazami jedno- i dwubiegunowymi. Natomiast przyjmując bardziej całościową perspektywę spojrzenia, to samo cierpienie można odczytać także jako element składający się na proces oczyszczającej i jednoczącej z Bogiem nocy, choć nie jest z nim tożsamy.

Psychiatra może zakwalifikować dany przypadek wyłącznie jako „kliniczny o patologicznej etiologii”. Mistyk natomiast będzie tłumaczył ów stan także jako „próbę wiary i łaskę Boga służąca przygotowaniu ludzkiej duszy do zjednoczenia z Nim”. Lekarz powie, że jest to „przypadek negatywny, z silną dominantą regresji”, z kolei mistyk określi ten casus jako „pozytywny, o wyjątkowym potencjale rozwojowym”. Święty Jan od Krzyża powie, że niektóre dusze Bóg

\footnotetext{
${ }^{52}$ Tamże, s. 247.

${ }^{53}$ Tamże, s. 167.
} 
wprowadza ,tylko czasowo w tę noc kontemplacji [...], okrywa je mrokiem, to znów oświeca" (NCII, I, 1), podczas gdy z punktu widzenia psychiatry może to być zaburzenie dwubiegunowe. Widzimy więc, że ten sam fenomen można interpretować co najmniej z dwóch stanowisk - medycznego i teologicznego. Obie płaszczyzny rozpatrywania tego samego zjawiska, choć są różne, jednak wcale się nie wykluczaja, ale mogą ze sobą współistnieć, tworząc bogatszy, pełniejszy wizerunek badanego zagadnienia ${ }^{54}$.

Podsumowując powyższe przemyślenia, dochodzimy do wniosku, iż opis biernej nocy ducha w drugiej księdze Nocy ciemnej stanowi przesłankę do twierdzenia, że sanjuanistyczna noc, choć nie jest tożsama ze stanem chorobowym, może jednak być miejscem rozgrywania się zaburzeń, które można określić mianem depresji endogennej ${ }^{55}$. Obydwie te rzeczywistości, chociaż są różne, łączy wiele podobieństw. Jedna i druga wiąże się z cierpieniem, poczuciem wewnętrznego rozbicia, pewnego rodzaju dezintegracją, która może być procesem pozytywnym, zwieńczonym ukształtowaniem się nowej tożsamości.

\section{Mysticism or Depression? \\ The Dark Night of St. John of the Cross and the Night of the Psyche}

\section{Summary}

The dark night of the soul described by St. John of the Cross and depression are two different realities, but they can penetrate each other and occur at the same time. These two phenomena, although different, share many similarities. One and the other involves some suffering, some kind of disintegration.

A breakdown of internal balance which the person may experience can be the basis for unity on a new level and the whole process can be crowned with reaching a new identity. The night of St. John of the Cross, although not identical with a disease state, can sometimes be a state of disorder that can be described as depression.

\section{Keywords}

St. John of the Cross, the dark night of the soul, depression

\section{Słowa kluczowe}

św. Jan od Krzyża, noc ciemna, depresja

\section{Bibliografia}

Barbaro de B., Duchowość w psychoterapii - psychoterapia w duszpasterstwie, w: J. Griffith, M.E. Griffith, Odkrywanie duchowości w psychoterapii, Kraków 2008, s. 8-15.

\footnotetext{
${ }^{54}$ J. Skawroń, Noc ducha..., dz. cyt., s. 245, 247.
}

${ }^{55}$ Tamże, s. 242. 
Brett G.S., Historia psychologii, PWN, Warszawa 1969.

Cantelmi T., Laselva P., Paluzzi S., Dialog psychologii z teologiq, Poznań 2006.

Catalan J., Depresja a życie duchowe, Kraków 2007.

Cummins N., Wprowadzenie do nauki św. Jana od Krzyża, thum. T. Kieniewicz, Kraków 2012.

Dąbrowski K., Dezintegracja pozytywna, Warszawa 1979.

Filek O., Wprowadzenie do dziet św. Jana od Krzyża, w: Jan od Krzyża, Dzieła, Kraków 2010, s. 47.

Forte B., Teologia e psicologia: resistenza, indifferenza, resa o integrazione?, w: Antropologia interdisciplinare e formazione, Bologna 1997, s. 75-95.

„Głos Karmelu” 20(2008) nr 2, s. 22-24.

Gic J., Noc czynna wg św. Jana od Krzyża a psychologia, Poznań 2009.

Gogola J., Wprowadzenie, w: Jan od Krzyża. Dzieła, Kraków 2010, s. 493.

Grzywocz K., Ból ludzkich zranień i potrzeba przebaczenia, konferencje wygłoszone w Centrum Duchowym Salwatorianów w Krakowie.

Kępiński A., Melancholia, Kraków 1993.

Skawroń J., Noc ducha i dezintegracja pozytywna, Kraków 2007.

Sobór Watykański II, Konstytucja duszpasterska o Kościele w świecie współczesnym Gaudium et spes, Watykan 1956.

Stein E., Wiedza Krzyża. Studium o św. Janie od Krzyża, Kraków 1994. 